\title{
USING EXPRSSION CARD MEDIA TO IMPROVE THE STUDENTS'SPEAKING SKILL AT THE SECOND GREAT OF SMA NEGERI 1 PAREPARE
}

\author{
Widya Pribadiyanti Areski ${ }^{1}$, Muzdalifah Muhammadun ${ }^{2}$, Amzah Selle $^{3}$ \\ English Program, Tarbiyah Faculty, State Islamic Institute of Parepare ${ }^{123}$ \\ areskiwidya@gmail.com ${ }^{1}$
}

\begin{abstract}
This research aims to see the students' speaking skill before and after learning process by using expression card media at the second grade of SMA Negeri 1 Parepare. The results of the research are useful for the teacher and students. The teacher should aware that it is important to supplied the technique or strategy before teachingand the students also can be easier to express their ideas, make the students more active in learning process. The subject of this research is XI IIS4 class which is consisted of 30 students. The sample was taken by using simple random sampling. The design in this research was pre-experimental with pre-test and post-test design. The student did the pre-test, got the treatment and did the post-test. Then the criteria of speaking skills are fluency, accuracy, content, pronunciation and they were usedto measure the students' speaking skill. It aimed to know whether using expression card media can improve the students' speaking skill. The result in this research was indicated that there was improvement of the students' speaking skill. It was indicated by the students' mean scoreof post-test (73.3) was greater than pre-test (41.9). Even, for the level significant $(\mathrm{p}) 5 \%$ and $(\mathrm{df})=\mathrm{N}-1=30-1=29$, and the value of table is 1.699 , while the value of t-test is 16.18. it means that, the t-test value is greater than t-table $(16.18 \geq 1.699)$. Thus, it can be concluded that the students' speaking skill is significant better after getting the treatment. So, the null hypothesis $\left(\mathrm{H}_{0}\right)$ is rejected and the alternative hypothesis $\left(\mathrm{H}_{\mathrm{a}}\right)$ is fail rejected.
\end{abstract}

Keywords: Speaking Skill, Expression Card Media.

\section{Introduction}

Language is an important thing for people to communication each other. People are able to express thought and feeling by using language. In this globalization era, the communication carries the paramount momentous. The importance of communication skill is relatively extraordinary. Those skills are awfully needed in every single part of life to be success people. By having more knowledge about language skill people have much better understanding and 
getting what we want as well as our needed. Besides, one of the important languages that should be known by the people in this world is English because English as a tool to communicate with the people from the other country. Mastering in English, people should know the language skill and element skill in English.

As people learn a foreign language e.g. English, they will involve in the process of learning four kinds of skill namely listening, reading, speaking, and writing (Kaharuddin, 2014). These language skills can be developed in language components namely pronunciation, structure and vocabulary. Nowadays living without knowledge of language, especially speaking of English. People will difficulties in communication and get interaction among individual and group, because people use language for producing their ideas, feeling, as well as wishes. That is why speaking is one of important skill that show how useful in daily life. Speaking is one of the important and significant skills that must be practiced to communicate orally. Through speaking people are able to know what kind of situations in the world. Does people who have competence in speaking were better in sending and receiving information or message to each person. In oral communication is a two-ways process between speaker and listener and that involves the productive skill of speaking and receptive skill of understanding (Kaharuddin, 2013).

The productive are consist of speaking and writing. It should produce the text meaningful in the nature of communication to make the listener acquired the message and the feedback from the speaker. While receptive skill includes understanding what people are listening and reading, receive the language and decode the meaning to understand the message.

The writer focuses in one of skills in English that is speaking. It is assumed that many students are still not active in spoken language when compared with other capabilities. Therefore, more efforts are teachers required to solve the problems, especially in speaking ability. Based on the previous observation at the second grade of SMA Negeri 1 parepare the writer got information from the students and English teacher to know the students' problems 
in speaking skill. It was found that the students were difficult to speak, it is able to prove that when the students are asking to speak in the class they do not know what should they are saying or do not have material to express. Most of students got bored in learning speaking class because it was not interesting. The activities of the students in the class were boring such as discussion some topics, making the conversation and reading materials in front of class. To make worse, the students had poor vocabulary so that they could no talk much about the topic.

In fact, there are a lot of way to improve the students' speaking skill for instance, yes-no answering, debating and etc. This way can be a tool of students' speaking skill. Commonly, as the way above cannot change the students' way to express andto improve the students' opinion. In teaching speaking, the teacher needs a good technique or media to absorb information and ideas for making their students have a capability in English. The other side knowing the capability of speaking in the class, the writer recommends a media that able to make the students easier to express their ideas in speaking.

In accordance with the explanation and problem describes above, expression card media use to teach speaking to the second grade of SMA Negeri 1 Parepare was conduct in this research. Therefore, the title of this study is "Using Expression Card Media to Improve the Students" Speaking Skill at the Second Grade of SMAN 1 Parepare."

In relation with the background above, the problem of the research can be stated as follow. "Is using expression card media able to improve the students speaking skill?" The following are objectives of the research "To know the score of students' speaking skill before and after using expression card media and to find out the using expression card media is able to improve the students' speaking skill." Before giving the treatment, students are difficult to express their ideas and feeling orally in front of their friends because they are confused how to express their ideas and how to start their speaking. After giving treatment, the students felt happy and fun in learning English by using expression card media. It made them easier to express their ideas orally by using the expression card media and they felt fun because they could communicate and interact with their classmate using 
English because as long as the meeting, they not only speak individually but also, they spoke in a group.

\section{Method}

This research design of this research was a pre-experimental with pre-test and post-test design. The students did the pre-test, got the treatment and did the post-test. It aimed to know whether using expression card media especially in speaking skill can improve the students' Speaking at the second grade of SMA Negeri 1 Parepare. The following is the formula:

Where: R: Random

$\begin{array}{lll}\mathrm{R} \mathrm{O}_{1} & \mathrm{X} & \mathrm{O}_{2}\end{array}$

$\mathrm{O}_{1}$ : Pretest

$\mathrm{X}$ : Treatment

$\mathrm{O}_{2}$ : Posttest

The location of the research took a place at SMANegeri 1 Parepare. The research used the quantitative research that has several times to collect and analyze the data. So, the writer used more than one month for collecting the data

The population of the research was the second-year students' of SMANegeri 1 Parepare academic year 2017/2018. XI IIS 1, XI IIS 2, XI IIS 3, XI IIS 4, XI IIS 5, XI MIA 1, XI MIA 2, XI MIA 3, and XI MIA 4. The total of population was 288 students.

The sample was taken by using simple random sampling. The writer used this technique because it was easier to do for taking sample from many classes. The writer only random all the classes in the second grade and took one of the class as the sample. The class is XI IIS 4 which is consisted of 30 students as the sample in this research.

To collect data from the students, the research applied speaking test tofind out the students' speakingskill of the second-grade students of SMANegeri 1 Parepare. In collecting data, the writer focused on English speaking material to know the students' ability before and after did the treatment. Then the criteria of 
speaking are fluency, accuracy, content, pronunciation and they were used to measure the students' speaking skill. The writer used tape recorder as the aid of these activities, how the students' speakingskill influences, by using expression card media.

Table 1 Scoring formulation for students' speaking skill.

\begin{tabular}{|c|c|c|}
\hline Classification & Score & Criteria \\
\hline \multirow{5}{*}{ Fluency } & $9-10$ & - Directly explain completely \\
\hline & $7-8$ & - Explain completely while thinking \\
\hline & $5-6$ & - Explain but not complete \\
\hline & $3-4$ & - Explain while thinking but not complete \\
\hline & $1-2$ & - Answer nothing right \\
\hline \multirow{5}{*}{ Accuracy } & $9-10$ & - No mistake \\
\hline & $7-8$ & - One inaccurate \\
\hline & $5-6$ & - Two inaccurate word \\
\hline & $3-4$ & - Three inaccurate word \\
\hline & $1-2$ & - More than three inaccurate \\
\hline \multirow{5}{*}{ Content } & $9-10$ & - Message required is dealt with effectively \\
\hline & $7-8$ & $\begin{array}{l}\text { - Message required is dealt with effectively } \\
\text { but a little unsystematic }\end{array}$ \\
\hline & $5-6$ & $\begin{array}{l}\text { - Message required is adequately conveyed } \\
\text { and organized but some lost of detail }\end{array}$ \\
\hline & $3-4$ & $\begin{array}{l}\text { - Message is broadly conveyed but with } \\
\text { little subtlety and some lost of detail }\end{array}$ \\
\hline & $1-2$ & $\begin{array}{l}\text { - Inadequate or irrelevant attempts at } \\
\text { conveying the message }\end{array}$ \\
\hline \multirow{5}{*}{ Pronunciation } & $9-10$ & - Very good pronunciation \\
\hline & $7-8$ & - Good pronunciation \\
\hline & $5-6$ & - Fair pronunciation \\
\hline & $3-4$ & - Poor pronunciation \\
\hline & $1-2$ & - Very poor pronunciation \\
\hline
\end{tabular}

(Data' source of SMA Negeri 1 Parepare)

Scoring the Students' Speaking of Pre-test and Post-test

$$
\text { Score }=\frac{\text { Students' correct answer }}{\text { Max score }} \quad 100
$$

Table 2The classification students' score

\begin{tabular}{ccc}
\hline No. & Classification & Score \\
\hline 1. & Very good & $81-100$ \\
2. & Good & $61-80$ \\
3. & Fair & $41-60$ \\
\hline
\end{tabular}




\begin{tabular}{lcc}
\hline 4. & Poor & $21-40$ \\
5. & Very poor & $0-20$ \\
\hline
\end{tabular}

\section{Findings}

The writer gave some questions to the students' as the pre-test to know the students' speaking skill. Every student got the questions and answered it then the writer recorded the students' answers. After giving the pre-test to the students, the writer found out the result of students' speaking skill based on the criteria of speaking skill which are accuracy, fluency, content and pronunciation before giving treatment.

Table 3 The students' score in pre-test

\begin{tabular}{cccccc}
\hline & & \multicolumn{4}{c}{ Pre-Test of Students $\left(\mathbf{X}_{\mathbf{1}}\right)$} \\
\cline { 3 - 6 } No. & Name & $\begin{array}{c}\text { Max } \\
\text { Score }\end{array}$ & $\begin{array}{c}\text { Total Score } \\
(\mathbf{X})\end{array}$ & $\mathbf{X}_{\mathbf{1}}^{\mathbf{2}}$ & Classifucation \\
\hline 1 & AS & 40 & 50 & 2500 & Fair \\
2 & AK & 40 & 35 & 1225 & Poor \\
3 & AP & 40 & 38 & 1444 & Poor \\
4 & AN & 40 & 43 & 1849 & Fair \\
5 & AM & 40 & 78 & 6084 & Good \\
6 & AJ & 40 & 40 & 1600 & Poor \\
7 & AA & 40 & 35 & 1225 & Poor \\
8 & AN & 40 & 33 & 1089 & Poor \\
9 & AB & 40 & 33 & 1089 & Poor \\
10 & FR & 40 & 30 & 900 & Poor \\
11 & FI & 40 & 30 & 900 & Poor \\
12 & HA & 40 & 55 & 3025 & Fair \\
13 & IC & 40 & 30 & 900 & Poor \\
14 & JI & 40 & 33 & 1089 & Poor \\
15 & MP & 40 & 45 & 2025 & Fair \\
16 & MA & 40 & 63 & 3969 & Good \\
17 & AR & 40 & 43 & 1849 & Fair \\
18 & DG & 40 & 33 & 1089 & Poor \\
19 & AG & 40 & 30 & 900 & Poor \\
20 & MR & 40 & 68 & 4624 & Good \\
21 & ND & 40 & 30 & 900 & Poor \\
22 & NF & 40 & 33 & 1089 & Poor \\
23 & NR & 40 & 55 & 3025 & Fair \\
24 & AH & 40 & 33 & 1089 & Poor
\end{tabular}




\begin{tabular}{cccccc}
25 & ID & 40 & 53 & 2809 & Fair \\
26 & ZR & 40 & 43 & 1849 & Fair \\
27 & PN & 40 & 35 & 1225 & Poor \\
28 & RC & 40 & 30 & 900 & Poor \\
29 & TZ & 40 & 30 & 900 & Poor \\
30 & ZD & 40 & 70 & 4900 & Good \\
\hline & Total & & $\Sigma \mathbf{X}=\mathbf{1 2 5 7}$ & $\Sigma \mathbf{X}^{\mathbf{2}}=\mathbf{5 8 0 6 1}$ & \\
\hline
\end{tabular}

(Data' Source: the students' score in pre-test)

Table 4The Rate Percentage of The Frequency of The Pre-Test

\begin{tabular}{ccccc}
\hline No. & Classification & Score & $\begin{array}{c}\text { Frequency of } \\
\text { Pre-Test }\end{array}$ & $\begin{array}{c}\text { Percentage of Pre- } \\
\text { Test }\end{array}$ \\
\hline 1. & Very Good & $81-100$ & 0 & $0 \%$ \\
2. & Good & $61-80$ & 4 & $13 \%$ \\
3. & Fair & $41-60$ & 8 & $27 \%$ \\
4. & Poor & $21-40$ & 18 & $60 \%$ \\
5. & Very poor & $0-20$ & 0 & 0 \\
\hline & Total & $\mathbf{3 0}$ & $\mathbf{1 0 0 \%}$ \\
\hline
\end{tabular}

(Data source: The rate percentage of the frequency of pre-test)

Meanwhile, the students' score in post-test would be presented in the following table:

Table 5 the students' speaking score in post-test

\begin{tabular}{cccccc}
\hline & & \multicolumn{4}{c}{ Post-Test of Students $\left(\mathbf{X}_{\mathbf{2}}\right)$} \\
\cline { 3 - 6 } No. & Name & Max Score & $\begin{array}{c}\text { Total } \\
\text { Score }(\mathbf{X})\end{array}$ & $\mathbf{X 2}^{\mathbf{2}}$ & Classifucation \\
\hline 1 & AS & 40 & 85 & 7225 & very good \\
2 & AK & 40 & 75 & 5625 & Good \\
3 & AP & 40 & 73 & 5329 & Good \\
4 & AN & 40 & 78 & 6084 & Good \\
5 & AM & 40 & 90 & 8100 & very good \\
6 & AJ & 40 & 73 & 5329 & Good \\
7 & AA & 40 & 68 & 4624 & Good \\
8 & AN & 40 & 83 & 6889 & very good \\
9 & AB & 40 & 75 & 5625 & Good \\
10 & FR & 40 & 75 & 5625 & Good \\
11 & FI & 40 & 65 & 4225 & Good \\
12 & HA & 40 & 80 & 6400 & Good \\
13 & IC & 40 & 70 & 4900 & Good \\
14 & JI & 40 & 68 & 4624 & Good
\end{tabular}




\begin{tabular}{llllll}
15 & MP & 40 & 68 & 4624 & Good \\
16 & MA & 40 & 73 & 5329 & Good \\
17 & AR & 40 & 75 & 5625 & Good \\
18 & DG & 40 & 78 & 6084 & Good \\
19 & AG & 40 & 65 & 4225 & Good \\
20 & MR & 40 & 80 & 6400 & Good \\
21 & ND & 40 & 68 & 4624 & Good \\
22 & NF & 40 & 70 & 4900 & Good \\
23 & NR & 40 & 75 & 5625 & Good \\
24 & AH & 40 & 70 & 4900 & Good \\
25 & ID & 40 & 73 & 5329 & Good \\
26 & ZR & 40 & 65 & 4225 & Good \\
27 & PN & 40 & 65 & 4225 & Good \\
28 & RC & 40 & 65 & 4225 & Good \\
29 & TZ & 40 & 73 & 5329 & Good \\
30 & ZD & 40 & 78 & 6084 & Good \\
\hline
\end{tabular}

(Data' Source: the students' score inpost-test)

Table 6 the rate percentage of the frequency of the post-test

\begin{tabular}{ccccc}
\hline No. & Classification & Score & $\begin{array}{c}\text { Frequency of } \\
\text { Pre-Test }\end{array}$ & $\begin{array}{c}\text { Percentage of } \\
\text { Pre-Test }\end{array}$ \\
\hline 1. & Very Good & $81-100$ & 3 & $10 \%$ \\
2. & Good & $61-80$ & 27 & $90 \%$ \\
3. & Fair & $41-60$ & 0 & $0 \%$ \\
4. & Poor & $21-40$ & 0 & $0 \%$ \\
5. & Very poor & $0-20$ & 0 & $0 \%$ \\
\hline & Total & & $\mathbf{3 0}$ & $\mathbf{1 0 0 \%}$ \\
\hline
\end{tabular}

(Data' source: The rate percentage of the frequency of post-test)

The table above shows the result of students' improvement in speaking skill after applying treatment through expression card media. There were three students got very good score and twenty-seven students got good score. It means that the students' speaking skill had improved through expression card media. The total score in post-test was 2199. It proved that there was improving of students' score in post-test. In addition, the result of post-test showed that no students had fail classification. 
Table 7 the mean score and standard deviation of pre-test and post-test

\begin{tabular}{|c|c|c|}
\hline Test & Mean Score & Standard Deviation (SD) \\
\hline Pre-test & 41.90 & 13.60 \\
Post-test & 73.30 & 2.24 \\
\hline
\end{tabular}

(Data' source: The mean score and standard deviation of pre-test and post-test)

The data in table 7 shows that the mean score of pre-test was $41.90\left(\mathrm{X}_{1}\right)$ while the mean score of the post-test increased $73.30\left(\mathrm{X}_{2}\right)$. The standard deviation of pre-test was 13.60 while the standard deviation of post-test was 2.24.

As the result at this item, the mean score of the post-test was greater than the mean score in pre-test. It means that students' speaking skill had improvement after doing the learning process that used expression card media.

Table 8 The Rate Percentage of the Frequency of The Pre-Test and Post-Test

\begin{tabular}{|c|c|c|c|c|c|c|}
\hline \multirow{2}{*}{$\begin{array}{c}\text { No } \\
\text { • }\end{array}$} & \multirow{2}{*}{ Classification } & \multirow{2}{*}{ Score } & \multicolumn{2}{|c|}{ Frequency } & \multicolumn{2}{|c|}{ Percentage } \\
\hline & & & Pre-Test & Post-Test & Pre-Test & Post-Test \\
\hline 1. & Very Good & $\begin{array}{l}81- \\
100\end{array}$ & 0 & 3 & $0 \%$ & $10 \%$ \\
\hline 2. & Good & $61-80$ & 4 & 27 & $13 \%$ & $90 \%$ \\
\hline 3. & Fair & $41-60$ & 8 & 0 & $27 \%$ & $0 \%$ \\
\hline 4. & Poor & $21-40$ & 18 & 0 & $60 \%$ & $0 \%$ \\
\hline 5. & Very Poor & $0-20$ & 0 & 0 & $0 \%$ & $0 \%$ \\
\hline & Total & & 30 & 30 & $100 \%$ & $100 \%$ \\
\hline
\end{tabular}

The data of the table above indicated that the rate percentage of the pretest. Four students got good score (13\%), and eight students got fair score (27\%), while the rate percentage of the post-test, three students got very good score (10\%), twenty-seven students got good score (90\%). The percentage in post-test that students got very good score was higher than percentage in pre-test. It showed that students were able to improve the students' speaking skill after treatment by using expression card media.

The implementation of using expression card media to improve the students' speaking skill at the second grade of SMA Negeri 1 Parepare. 
Table 9 the test of significant

\begin{tabular}{ccc}
\hline Variable & T-test & T-table value \\
\hline Pre-test - post-test & 16.18 & 1.69 \\
\hline
\end{tabular}

\section{Discussion}

Inteaching speaking for high school students, an English teacher should be able to use the appropriate way in order to make the students be more enthusiastic and interested in speaking English. Harmer (2007, p. 136) explains the expression card media is a small card which students use in pair or group work. By using expression card media students will be more interested. In learning since they are able to link between the materials with the image or script. It is clear expression card media can make students interact with other students. When they are interacting, they can improve their speaking achievement. Every student can learn from their mistake or from their friends. It will be more effective rather than just sit and learn in the class. Not all the students will be interested in that activity but at least the teacher can make students speak English briefly.

In this research, the writer focused on students' speaking skill and expression card media as the method in teaching speaking. Based on the informal interview with the students and English teacher in preliminary study, many problems were found in learning speaking. The students were difficult to speak in front of the class because it was not interesting. The activities of the students in the class such as discussing some topics, reading materials in front of the class. To make it worse, the students had poor vocabulary so that they could not talk much about the topic and make the student stiff then lost in confidence.

\section{Conclusions}

Based on the result of data analysis and the discussion of the result in previous chapter, the finding of the result showed the positive impact in the students' speaking skill and class situation. This study is categorized preexperiment research design, the objective in this study is to find out whether using expression card media was able or not to improve the students' speaking skill. Therefore, the writer concluded that there is a significant difference of the 
students' speaking skill before and after treatment. It can be seen the students' speaking before applying expression card media or did treatment. The writer gave the students pre-test with result of mean score was 41.9 and standard deviation was 13.6. While the students' speaking after applying expression card media or did treatment, the writer gave post-test with several questions and the result of the mean score was 73.30 and standard deviation 2.24.

It can be proved by looking at the mean score of the students' speaking test in pre-test and post-test. The mean score of pre-test is lower than the mean score of post-test. Then the T-test result in which the value of t-test was 16.18. It was greater than t-table 1.699 at the level significance 0,05 and degree of freedom (df) was 29. It means that the null hypothesis $\left(\mathrm{H}_{0}\right)$ was rejected and the alternative hypothesis $\left(\mathrm{H}_{\mathrm{a}}\right)$ was fail rejected.

Finally, using expression card media could help the students in learning English, the students will not confuse what they want to say when the teacher asks them and most of them easier to express their ideas. It means this technique able to be used in learning process.

\section{References}

Arikunto, Suharsimin. 2009. Dasar-dasarEvaluasiPendidikan. Jakarta: BumiAksara.

Bahar, A. kaharuddin. 2013. The Communicative Competence-Based English Language Teaching. Yogyakarta: Trust Media Publishing. 2014. Interactional Speaking. Yogyakarta: Trust Media Publishing. 2014. Transactional Speaking. SamataGowa: GunaDarmaIlmu.

Bungin, Burhan. 2005. Metode Penelitian KuantitatifJakarta: Kencana Pradana Media.

Celce-Murcia, Marianne. 1991. Teaching English As Second or Foreign Language. Bosto: Heinle Publisher.

Elsa EkaPutri. 2014. "Using Cue Card Media to Improve TheStdents' Speaking Ability at the second year of SMK Negeri 4 Pinrang" Unpublished Scrips; English Department: Parepare.

Gay L.R. 1981. Educational Research Competencies for Analysis and Application. second edition. Columbus: Charles E. Meril Publising Company. 
Hany WahyuniWulandari. "Using Download Audio in Teaching Speaking," SitusResmiWordpress.com.http://hanywahyuwulandari.wordpress.com/cate gory/uncategorized/

Harkoyo, Sapto. 2009. "EfektifitasPemanfaatan media Audio-Visual SebagaiAlternatifOptimalisasiModel JurnalEdukasi@Elektro5,no 1. pembelajaran,"

Harmer, Jeremy. 2002. The Partice of English Languge Teaching; Fourth Edition. England: Longman Pearson.

MCDonough, Jo and Christoper Shaw. 1993. Material and Methods in ELT: A Teacher Guide. Cambridge:Blackwell Publisher.

Muh. Akmaluddin. 2011. "Improving the Speaking Ability to The Students by Using Question Cards of SMA Negeri 1 Belawa" UnpublisedScrips; English Department: Parepare.

Nurhayati, Siti. 2011. "Teaching SpekingSkill Trough Communicative Language Teaching." Published Skripsi; Department of English Education: Jakarta.

O'Malley, J. Michael and Lorraine Valdez Pierce. 2005. Authentic Assessment for English Language Learners. United State: Pearson Longman.

Oxford. 2008. Oxford Learners' Pocket Dictionary; Fourth Edition. New York: Oxford University Press.

Richard, Jack C. 2008. Teaching Listening and Speaking from Theory to Practice. Cambridge University.

Sanu, Dasna. 2014. "Using Information card to Stimulate Students Speaking Ability of the second Year Students of MTs DDI TaqwaParepare" Unpublished Scrips; English Department: Parepare.

Sekolah Tinggi Agama Islam Negeri (STAIN). 2013. Pedoman Penulisan Karya Ilmiah. Parepare: Departemen Agama.

Sri Lestari, Ambar. 2014. "PembuatanBahan Ajar BerbasisModulPadaMatakuliah Media Pembelajaran Di JurusanTarbiyah Stain Sultan QaimuddinKendari," Jurnal Al-Ta'dib 7, no. 2.

Sugiyono. 2015. "MetodePenelitianKuantitaif, Kualitatif, dan R\&D." Bandung: Alfabeta.

Suhaimin, Neneng. 2014. "The EffectivinessOf Using Flash Card In Teaching Vocabulary." Published Skripsi; Department of English Education: Jakarta.

Unesco. 2006. A Kit for Teachers, Students, Parents and Professiona.L'exprimeur - Paris.

Webster's Third New International Dictionary 